this is essential and we urge Lao's CITES, customs and police authorities to work closely with enforcement officers in neighbouring countries and especially in China.

VINCENT NIJMAN Oxford Wildlife Trade Research Group, Department of Anthropology and Geography, Oxford Brookes University, Oxford, OX3 OBP, UK

E-mailvnijman@brookes.ac.uk

Chris R. Shepherd TRAFFIC South-East Asia, Petaling Jaya, Malaysia

\section{International trophy hunting in China}

On 5 August 2011 the national wildlife management authority in the State Forestry Administration of China held an expert consultative meeting on the issue of whether or not to permit the hunting of seven Tibetan gazelles Procapra picticaudata and blue sheep Pseudois nayaur by international trophy hunters in the Dulan International Hunting Ground, Qinghai Province. The applications were submitted by two travel agencies in Beijing on behalf of foreign clients. The consultative meeting, which was opened to the media, was an attempt to reopen international trophy hunting in China following 5 years of suspension. The meeting voted to recommend the reopening of trophy hunting. This news, aired on television, websites and newspapers, stimulated a heated debate about international trophy hunting.

The Qinghai-Tibetan Plateau is home to many endemic species. Before the wildlife protection law was implemented in 1989 many wild animals were hunted on the Plateau: 1.5 million wild animal skins, 271,742 wildfowl and 2.6 million t of game meat were sold between 1965 and 1975. A further 2.9 million wild animal skins, 60,559 wildfowl and 2.1 million t of game meat entered domestic markets from 1976 to 1985 . Hunting was banned nationwide and all sporting firearms were required to be surrendered to the police in 1994. Thus, at present there is no legal hunting permitted in China except in a few approved hunting grounds where artificially bred hare, pheasants and deer are released for recreational hunting. However, international trophy hunting had previously been permitted because hunters harvested a limited number of wild animals and paid a high trophy fee. For example, in the early 1980 s it cost USD 45 to hunt a blue sheep as game meat for sale on the international market but the fee paid by a foreign hunter to hunt a blue sheep as a trophy animal was USD 5,900, plus service and conservation fees. Trophy hunting resulted in reduced hunting pressure on ungulates inhabiting the Plateau while simultaneously generating funds for conservation management and pasture compensation for indigenous herdsmen. Furthermore, herdsmen began to care about the blue sheep because their value to international trophy hunters translated into revenue for the local economy.

Opinion was sharply divided in the debate about the reopening of trophy hunting. Those in favour argued that hunting is widely practised internationally as a management tool to regulate wild animal populations and as a mechanism to generate revenue that is channelled back into local economies and resource management. Principles of conservation and sustainable use of wild animal resources are embodied in CITES and national laws. Experience of trophy hunting in Australia, North America, southern Africa and Mongolia has demonstrated that trophy hunting can achieve successful protection of wild animals and their habitats, create an effective funding base for conservation management, improve local livelihoods and stimulate participation of indigenous peoples.

On the other hand those against were ideologically opposed to any animal being killed for any reason. This group of people formed an alliance to oppose the reopening of trophy hunting. In wide discussion on the internet it was clear that many people either did not believe the results of recent censuses in Dulan International Hunting Ground, which indicate that the populations of blue sheep and Tibetan gazelle are rebounding, or were sceptical that funds generated from trophy hunting would be allocated for conservation.

In the event, however, on 5 September 2011 the two travel agencies in Beijing withdrew their trophy hunting applications to the State Forestry Administration because 'their foreign clients could not make the trophy hunting trip within the time constraints'. Thus trophy hunting in China remains banned.

ZhigANG JiANG and CHUNWANG LI Key Laboratory of Animal Ecology and Conservation Biology, Institute of Zoology, Chinese Academy of Sciences, Beijing, China 100101

E-mail jiangzg@ioz.ac.cn

ROBERT W.G. JENKINS Creative Conservation Solutions, Belconnen Australian Capital Territory, Australia

JIE ZHENG Wild Animal Conservation Bureau, Qinghai Province, Xining, China

\section{3th Conservation Workshop for the Biodiversity of Arabia}

The 13th Annual Conservation Workshop for the Biodiversity of Arabia was held at the Breeding Centre for Endangered Arabian Wildlife (BCEAW) in Sharjah, UAE, on 7-9 February 2012. This regional forum brought together 106 participants representing UAE, Jordan, Saudi Arabia, Bahrain, Kuwait, Egypt, Yemen and Oman, and from the USA, UK, South Africa, Zambia, Germany, Italy and 
New Zealand. The Sharjah workshops are hosted by the Environment and Protected Areas Authority (EPAA) of the Government of Sharjah, under the patronage of His Highness Sheikh Dr Sultan bin Mohammed al Qassimi.

The Workshop continued the parallel processes of protected areas and species-focused themes established since 2006. The protected areas theme looked at two aspects raised during management effectiveness evaluations in previous years: engagement of local communities and the related issue of protected area zonation. Country reports from the region (Oman, UAE, Jordan, Yemen, Saudi Arabia) indicated a wide range of levels of engagement with local stakeholders. Most commonly the level of participation by local communities in the creation and management of protected areas involves consultation, topdown benefit sharing and the development of management agreements, rather than full co-management or the devolution of authority and responsibility to community groups. The most common regional protected area governance types are government managed protected areas, particularly with a national, federal or local ministry, or a government delegated NGO in sole charge. Least common are private protected areas and community conserved areas, although traditional local resource management structures in Saudi Arabia (hema) could be revived to fit this model. Key challenges and obstacles to greater community management of protected areas were identified and some regionally relevant approaches and guiding principles recognized.

Protected area case studies revealed a range of zonation schemes being proposed or applied, namely: core zones of strict protection, wider use zones facilitating visitor access and low-impact nature-based tourism, and buffer zones within the protected areas to minimize negative impacts from surrounding developments and threats. The need to integrate protected area zoning into regional land-use planning initiatives was stressed as an important means of reducing threats to protected areas. Having a wellarticulated vision and objectives for the protected area facilitated the development of appropriate zonation plans. Similarly, key challenges and guiding principles associated with protected area zonation were identified by workshop participants.

The species-focused theme of the Workshop entailed a regional Red List assessment of 150 reptile species of the Arabian Peninsula, in collaboration with the Conservation International/IUCN Biodiversity Assessment Unit, and involving several regional and international experts. Only eight species were listed in one of the three categories of threat (four Endangered and four Vulnerable), with 21 species considered Data Deficient, and the remainder (121) listed as Near Threatened (NT) or Least Concern (LC).

For the first time the Workshop included a technical training component, with 2 days of hands-on exercises, regional case studies, and equipment assessments relating to the application, coordination and standardization of camera trapping for conservation management.

PHILIP SEDDON Department of Zoology, University of Otago, PO Box 56, Dunedin, New Zealand

E-mail philip.seddon@stonebow.otago.ac.nz

MIKE KNIGHT South African National Parks, and Department of Zoology, Nelson Mandela Metropolitan University, Humewood, Port Elizabeth, South Africa

DAVID MALLON Manchester Metropolitan University, UK, and Co-Chair, IUCN/Species Survival Commission Antelope Specialist Group 